九州大学学術情報リポジトリ

Kyushu University Institutional Repository

Geological and Petrological Studies of the "Shirasu" in South Kyushu, Japan Part II. : Preliminary Note (2)

Taneda, Sadakatu

Faculty of Sciences, Kyushu University

https://doi.org/10.5109/1524305

出版情報：九州大學理學部紀要：Series D, Geology. 6 (2)，pp.91-105，1957-05-31. Faculty of Science, Kyushu University バージョン：

権利関係 : 
Mem. Fac. Sci., Kyushu Univ., Ser. D, Geology, Vol. VI. No. 2

pp. 91-105, text-fig. 12, tables 1-3, May, 1957

\title{
Geological and Petrological Studies of the "Shirasu" in South Kyushu, Japan \\ Part II. Preliminary Note $(2)^{*}$
}

By

\author{
Sadakatu TANEDA
}

\section{Introduction}

In my previous paper (TANEDA, 1954), I gave the geological and petrological outlines of the "Shirasu," the wide-spread loose tufaceous deposits forming a vast table land in south Kyushu, and inferred that the "Shirasu" proper is a deposit formed by a succession of abnormal explosions, perhaps of the nuée ardente or pumice flow type.

It has been pointed out by Verhoogen (1951) that differences in the mode of explosive eruptions may depend more largely on the processes involved than on original differences in composition, gas content, and other properties of lavas, and by Moore (1934) that the distinction between normal and abnormal types of volcanic activity does not reflect in the chemical and mineral composition but in the field relationships and mechanical analyses of the erupted matters. In the case of the "Shirasu," I wished to make clear its geological and mechanical features, because our knowledge of them, especially of the latter, had been very poor. In this paper is given a more accurate knowledge obtainted during my last two-year investigation of the volcanic deposits.

\section{Shape of component fragments and particles}

1. Roughly speaking, the "Shirasu" has a general appearance of either loose lapilli tuff, or loose tuff breccia, or loose volcanic breccia, containing a conspicuous proportion of pumiceous and compact rock fragments and some whole or fragmented crystals. The pumiceous fragments vary in size: some range up to 10$20 \mathrm{~cm}$ and rarely to $100 \mathrm{~cm}$ in diameter, some are fine of ash-size, whereas others dust-size less than $1 \mu$ in diameter (Fig. 4).

2. The fragments are irregular in shape, being angular to subangular: sometimes they are rather rounded (Fig. 1) with a tendency that most larger ones are somewhat rounded, subrounded and subangular while most smaller ones are angular. Yet angularity of the fragments varies laterally and vertically in the "Shirasu" bed-a fact of geologic importance not to be overlooked, though it is not discussed in this paper.

\footnotetext{
* Received December 10, 1956.
} 


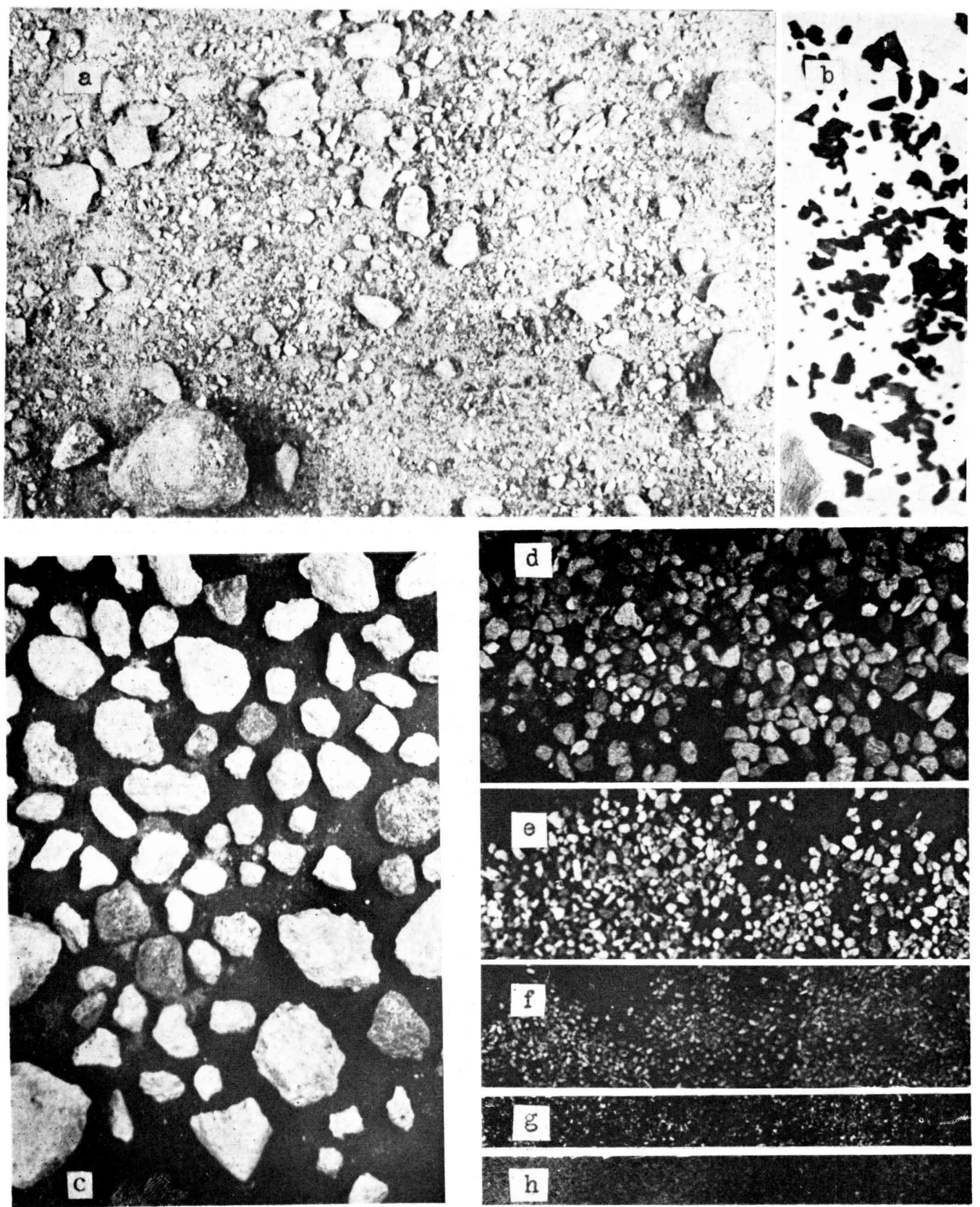

Fig. 1. Photographs of the fragments in the "Shirasu" from Tagami, Kagoshima City. a: "Shirasu," gray in colour, unbedded, and chaotic. Approximately natural size.

b: Photomicrograph of the ashy material in the "Shirasu." $\times 40$.

c: Fragments, more than $4 \mathrm{~mm}$ in minor diameter.

d: Do., $4.0-1.65 \mathrm{~mm}$ in minor diameter.

e: Do., $1.65-0.83 \mathrm{~mm}$ in minor diameter.

$\mathrm{f}$ : Do., $0.83-0.50 \mathrm{~mm}$ in minor diameter.

g: Do., $0.50-0.25 \mathrm{~mm}$ in minor diameter.

$\mathrm{h}$ : Do., less than $0,25 \mathrm{~mm}$ in minor diameter. 
3. The fine-grained clastic matrix is, as seen under the microscope, composed largely of particles of colourless glass having a rudely triangular shape with
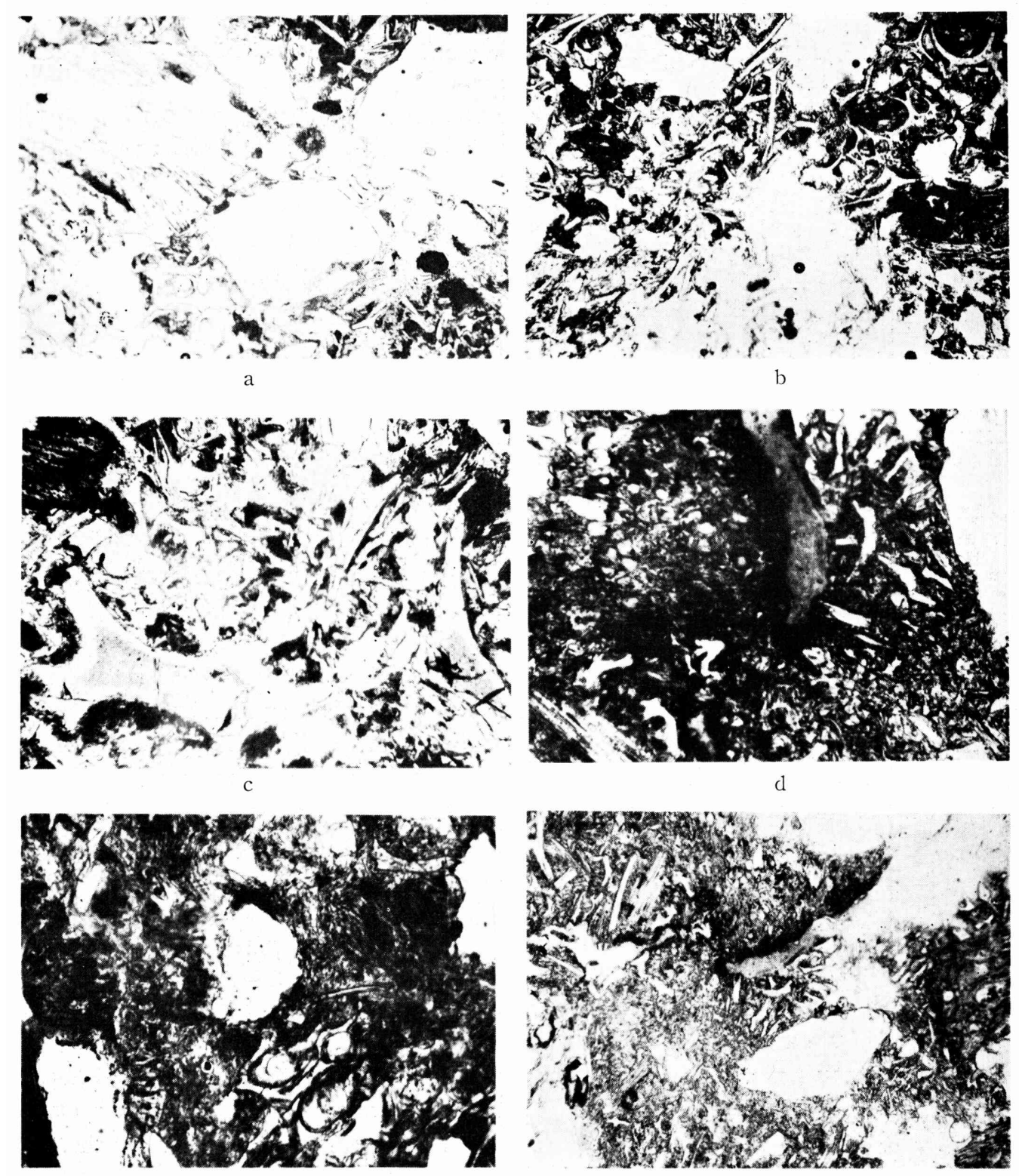

Fig. 2. Photomicrographs of some "Shirasu."

$\begin{array}{ll}\text { a: From Hiwaki Village. } & \times 37 . \\ \text { b: Do. } & \times 37 . \\ \text { c: From Tsuruda Village. } & \times 37 . \\ \text { d: From Ikawa, Tarumizu Town. } & \times 96 . \\ \text { e: Do. } & \times 96 . \\ \text { f: Do. } & \times 48 .\end{array}$


concave edges (Figs. 2, 3); the angular shape of the finest particles less than $1 \mu$ in diameter is clearly recognized by means of an electron microscope (Fig. 4). This characteristic shape may have been resulted by the disruption of pumice or
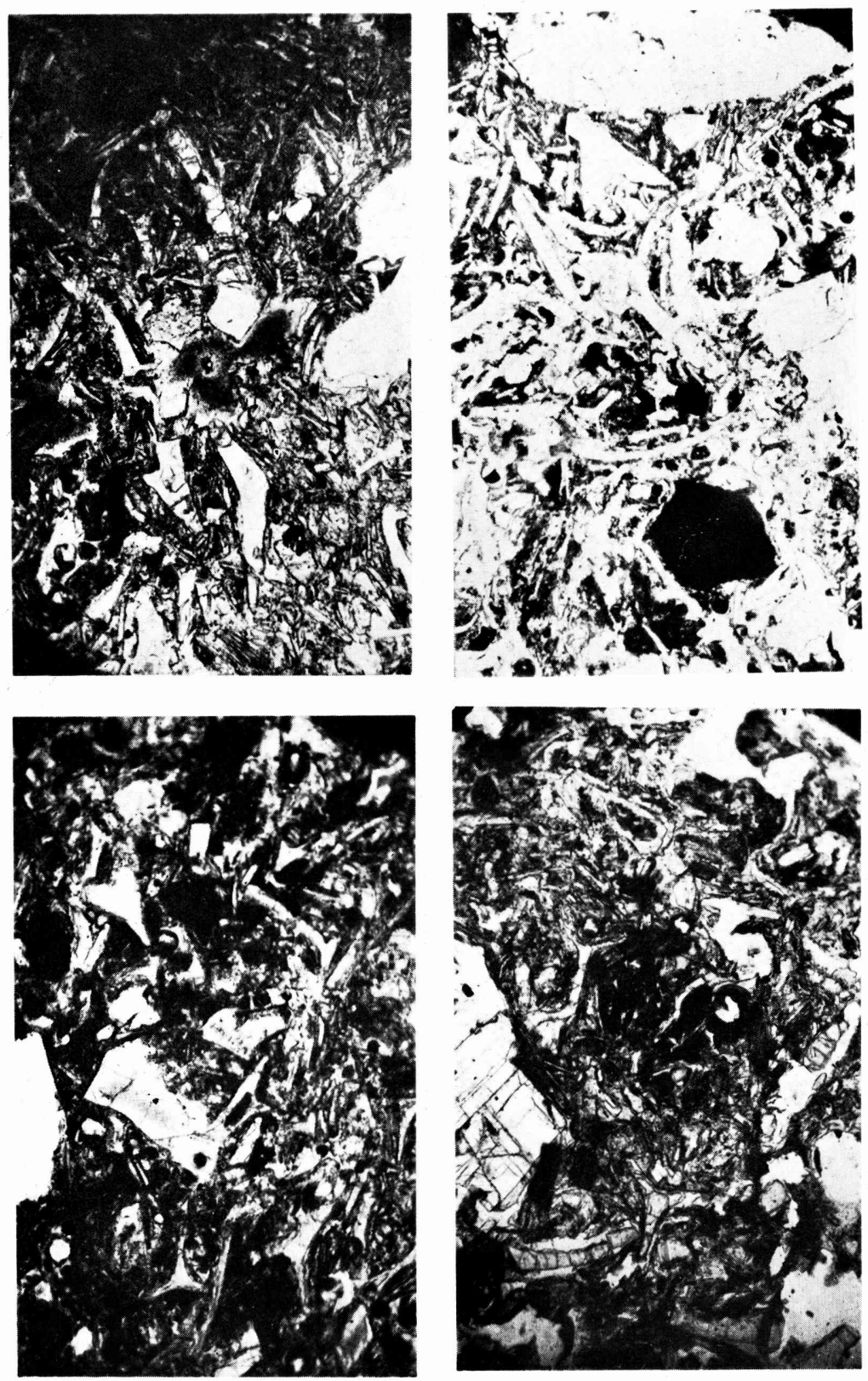

Fig. 3. Photomicrographs of the "Shirasu" from Tagami, Kagoshima City. $\times 37$.

Upper two show the vertical and lower two the horizontal sections. No distinct difference in texture is observed between the two kinds of section. 
Geological and Petrological Studies of the "Shirasu" in South Kyushu, Japan

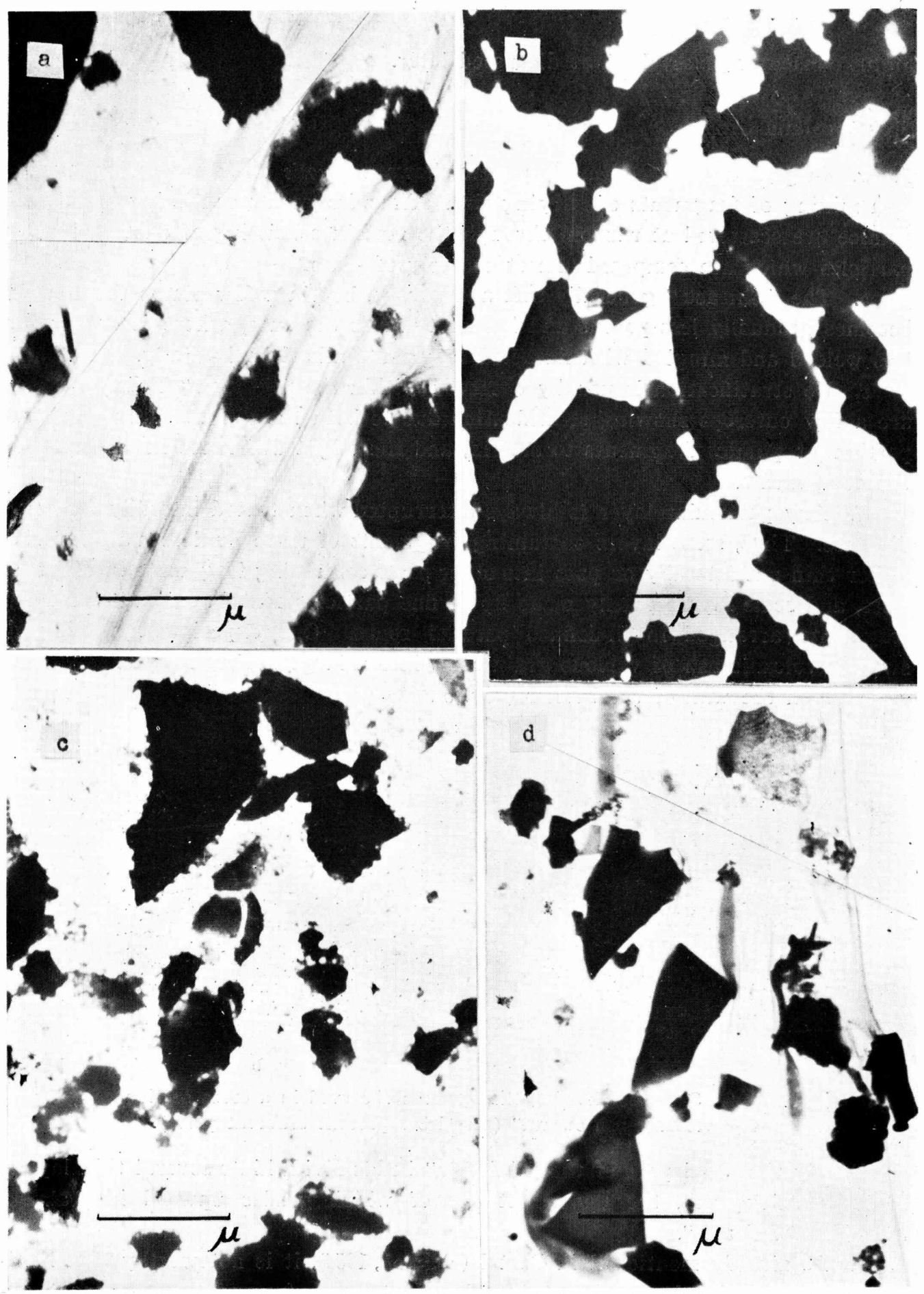

Fig. 4. Electron micrographs of the finest particles in the "Shirasu" (a, b, c) and in the "artificial Shirasu" (d).

a: "Shirasu" from the lower part of a cliff, Ikawa, Tarumizu Town. $\times 20,000$

b: "Shirasu" from the upper part of the cliff described above. $\quad \times 20,000$

c: "Shirasu" from Tagami, Kagoshima City.

d: Powders produced by rolling pumice fragments. 
highly vesicular glassy lava as discussed later.

\section{Structure and texture}

1. a. In general the "Shirasu" proper shows a chaotic structure owing to random mixing of fragments of varying size. Thus fragments consisting mainly of pumice are scattered at random through the matrix consisting of dust and ashy particles which are composed almost entirely of glass.

$b$. The "Shirasu" generally soft and porous, but in a few places the matrix becomes gradually less porous and harder towards the base, where it is more or less welded and mingled with flattened tragments alined horizontally.

$c$. No stratification is usually observed within the "Shirasu" bed, yet there are a few outcrops showing stratification due to both the difference in the proportion of pumice fragments to matrix, and the slight difference in the size of the components.

d. Any particular layer is always interrupted when traced laterally for some distance. Thus, some layers containing fragments of more or less uniform size either thin out laterally or pass into other parts containing fragments of different sizes, and some layers chiefly made up of fine particles contain somewhat coarser fragments arranged in ill-defined parallel zones. Our experiment rushing in swarms volcanic ash of various grain sizes into a large beaker illustrates similar features on the wall of the beaker (Fig. 5).

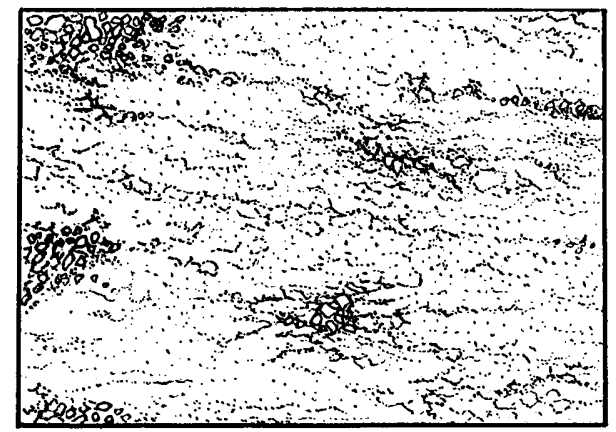

a

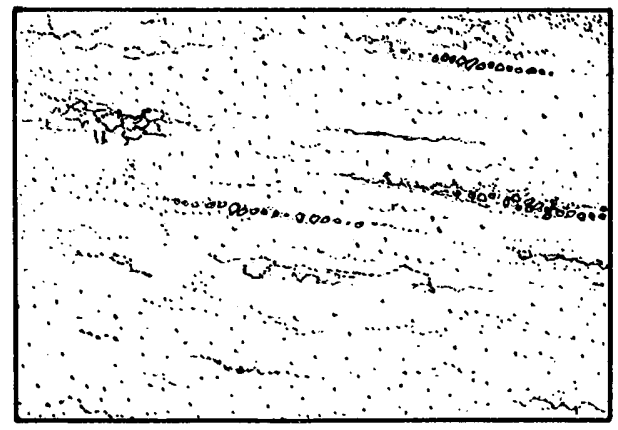

b

Fig. 5. Sketches showing the features observed in a cross section of "volcanic ash swarm" (a and b represent different parts).

Rarely the basal part of the "Shirasu" bed is divided into several thin layers, $20-40 \mathrm{~cm}$ thick each, the uppermost one of which grades upward into almost unbedded "Shirasu".

$e$. As already mentioned in Part I (TANedA, 1954), it is noteworthy that lenticular masses or bands, consisting largely of accessory fragments of compact andesite, are often intercalated in the "Shirasu" bed, as in certain pumice flows described by Kuno (1941).

The structure and texture described above show that the "Shirasu" is not 
a deposit of a single eruption but of several eruptions perhaps in a rapid succession, and that the circumstances of its accumulation would 'not have been uniform throughout the whole area.

2. The microscopic texture of the "Shirasu" was observed on many horizontal, vertical and oblique sections (Fig. 3) prepared from the sample (locality: Tagami, Kagoshima City) harden with a cementing agent "URIX" (commercial name for a kind of bakelite). It is noteworthy that in texture no noticeable difference is found between the horizontal, vertical and oblique sections, all showing a vitroclastic texture or Bogenstruktur and illustrating poor sorting (Figs. 2, 3).

\section{Size distribution}

1. In my previous paper (Part I), I pointed out that poor sorting revealed by the size distribution diagram of the tuff fraction of the "Shirasu" that excludes the fragments more than $4 \mathrm{~mm}$ in diameter denies our correlation of it with ordinary volcanic ash or loess commonly sorted well by air current, but suggests a certain similarity of the mode of origin between the "Shirasu" and Moore's "Older pumice" in the Crater Lake Region, Oregon (Moore, 1934). This view has been confirmed by our new results of mechanical analyses of the total bulk of the "Shirasu" (Table 1 and Figs. 6, 7; also see Part I, p. 175, Fig. 7).

Table 1. Size distribution of the "Shirasu." (Total of 100)

\begin{tabular}{|c|c|c|c|c|c|c|c|c|c|c|c|}
\hline Loc. No. Size $(\mathrm{mm})$ & $64-3$ & $32-1$ & $16-8$ & $8-4$ & $4-2$ & $2-1$ & $1-1 / 2$ & $1 / 2^{-1 / 4}$ & $1 / 4^{-1 / 8}$ & $/ 8^{-1 / 16}$ & $|16\rangle$ \\
\hline 1 & 2 & 3 & 5 & 8 & 6 & 8 & 13 & 14 & 13 & 22 & 6 \\
\hline 2 & 4 & 28 & 22 & 7 & 10 & 17 & 7 & 4.3 & 0.5 & 0.2 & 0 \\
\hline 3 & & 4 & 5 & 7 & 8 & 12 & 17 & 14 & 13 & 16 & 4 \\
\hline 4 & & 14 & 5 & 12 & 5 & 15 & 12 & 11 & 8 & 13 & 5 \\
\hline 5 & & 9 & 8 & 10 & 6 & 17 & 16 & 11 & 8 & 10 & 5 \\
\hline 6 & 6 & 2 & 5 & 7 & 6 & 13 & 15 & 17 & 17 & 10.5 & 1.5 \\
\hline
\end{tabular}

Nos. 1, 2, 3: Cliff at Ikawa, Tarumizu Town; $1:$ basal part, 3: upper part, 2: near the basal part, with an appearance of brecciated pumice or pumice flow.

Nos. 4, 5: Separated outcrops in Shin-mido, Tarumizu Town.

No. 6: $\quad$ Shiroyama, Kagoshima City.

2. For a full discussion about the source of material and the mechanism of "Shirasu" deposition, the data for median diameter $(\mathrm{Md})$, quartile diameter $\left(\mathbf{Q}_{\mathbf{1}}\right.$ • $\mathrm{Q}_{3}$ ), quartile kurtosis, may be available. Moreover the amount and dimension of respective larger and largest fragments at every locality may be worth recording (Shapp and Nobles, 1953). As regards them some remarks will be made in the near future. 

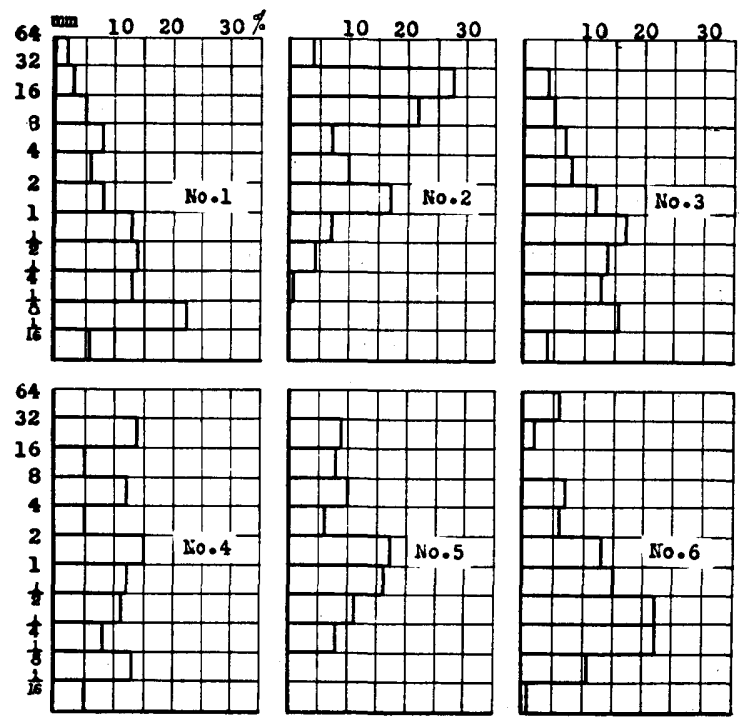

Fig. 6. Size-distribution diagrams for the "Shirasu." (Nos. refer to Table 1)

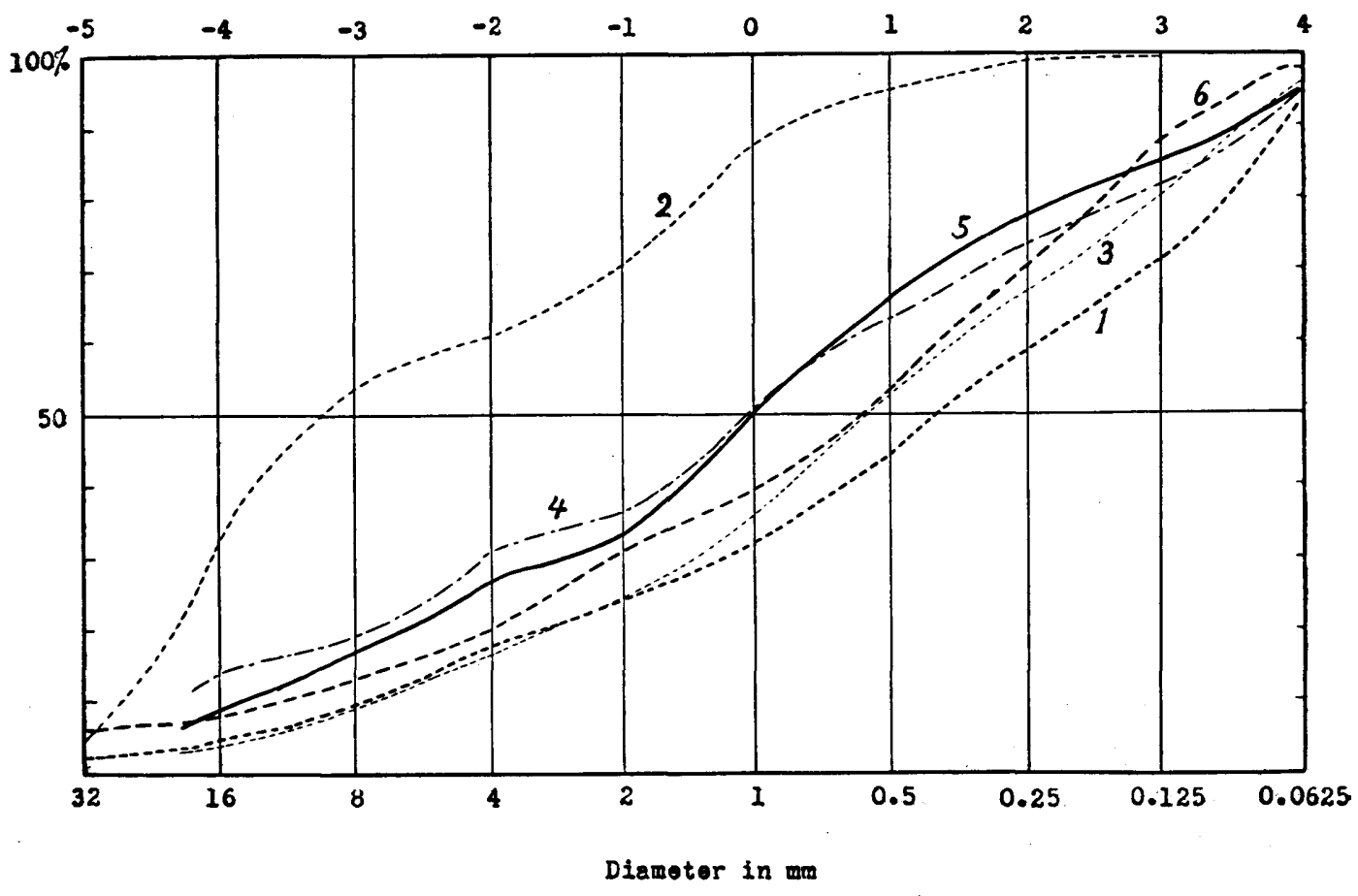

Fig. 7. Cumulative curves for the "Shirasu." (Nos. refer to Table 1) 


\section{Carbonized plants ${ }^{1)}$}

In frequent carbonized plants in the various forms of soot to natural charcoal of trunk remain in the unbedded "Shirasu." Some important facts about their modes of occurrence are summarized as follows:

1). Carbonized plants are not distributed uniformly through the "Shirasu" bed, but are found in certain limited areas.

2). If present, they occur, as seen on the sides of the "Shirasu" ciff, scattering at various levels, except the basal part.

3). Usually carbonized trunks are not standing upright, but are laid obliquely in the "Shirasu" which is unbedded. Inedeed a few carbonized plants are laid down almost horizontally, sometimes standing on the head in the unbedded "Shirasu.".

These facts seems to suggest that when the "Shirasu" swept down the side of a volcano it might have enfolded and baked or burned the vegetation in its path. Since the temperature of nuée ardente, according to Gillbert (1938), may vary in different eruptions and even in any one eruption ${ }^{2)}$, and since such is also the case with some pumice flows, we can expect the presence of trunks carbonized to varying degrees in the "Shirasu" bed.

\section{High temperature experiment and load bearing test}

1. The "Shirasu" was heated in an electric furnace at temperatures of 600,800 , $850,1000,1100$, and $1200^{\circ} \mathrm{C}\left( \pm 10^{\circ} \mathrm{C}\right.$, respectively) for $1-1.5$ hours. The changes are as follows: Through moderate heating colour changes from gray white to reddish or purplish gray, a reddish tinge being deepened with raising temperatures from 600 to $1000^{\circ} \mathrm{C}$. At a temperature between 850 and $920^{\circ} \mathrm{C}$, the "Shirasu" begins to melt, and at about $1200^{\circ} \mathrm{C}$ most part of it melts completely with the restoration of its original grayish colour.

Table 2. Load bearing test of pumice in the "Shirasu."

\begin{tabular}{|l|l|l|l|l|}
\hline $\begin{array}{l}\text { Deformation } \\
\text { percentage }\end{array}$ & No. Load $\left(\mathrm{kg} / \mathrm{cm}^{2}\right)$ & 1 & 2 & 3 \\
\hline Softening point & $<1$ & 3 & $5^{*}$ \\
$0.5 \%$ deformation point & $916^{\circ} \mathrm{C}$ & $880^{\circ} \mathrm{C}$ & $874^{\circ} \mathrm{C}$ \\
$1.0 \%$ & $934^{\circ}$ & $906^{\circ}$ & $803^{\circ}$ \\
$2.0 \%$ & $953^{\circ}$ & $921^{\circ}$ & $916^{\circ}$ \\
$3.0 \%$ & $964^{\circ}$ & $940^{\circ}$ & $928^{\circ}$ \\
$5.0 \%$ & $"$ & $978^{\circ}$ & $950^{\circ}$ & $934^{\circ}$ \\
\hline
\end{tabular}

*5 kg/ $\mathrm{cm}^{2}$ load corresponds approximately to $30 \mathrm{~m}$ thick "Shirasu."

1) The humice and peat rarely interbedded with thin "Shirasu"-like strata overlying or underlying the "Shirasu" proper are not described here.

2) LACRoIx (1904) reported so low a temperature as $210^{\circ} \mathrm{C}$ even in the material of nuées ardentes $6 \mathrm{~km}$ from the crater of the Mont Pelée eruption of 1902 . 
2. The load bearing test of the pumice in the "Shirasu" was (made in order to know the P-T conditions of welding in the "Shirasu," its results being shown in Table 2 and Figs. $8 a$ and $8 b$.

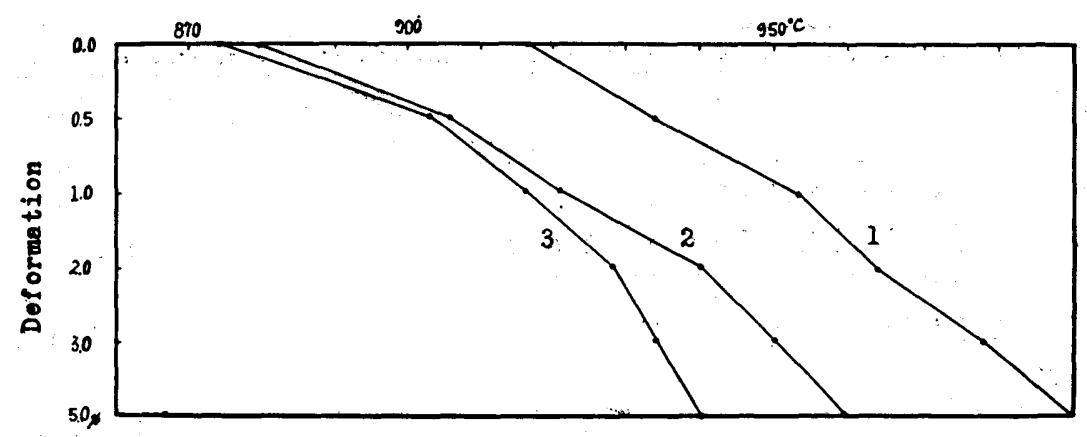

Fig. 8-a. Load bearing test of pumice in the "Shirasu."

1. load 0 ; 2. load $3 \mathrm{~kg} / \mathrm{cm}^{2} ; 3$. load $5 \mathrm{~kg} / \mathrm{cm}^{2}$.

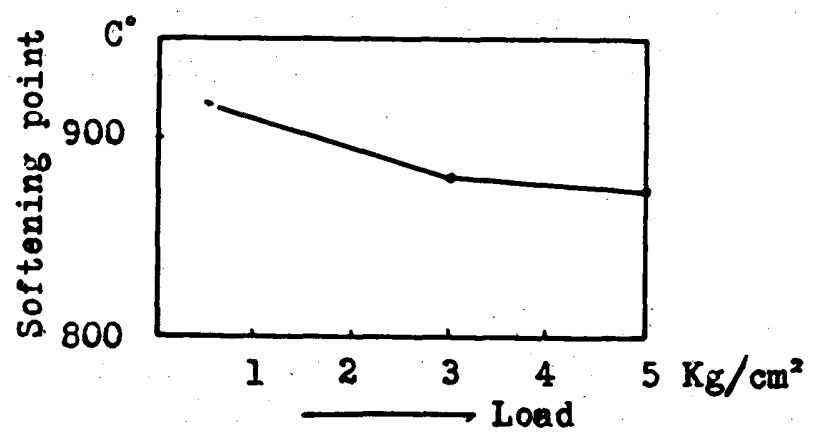

Fig. 8-b. Relationship between softening point and load.

From these experiments it is natural to expect that heating at temperatures below $920^{\circ} \mathrm{C}$ should make the "Shirasu" welded to take an appearance of the "Hai-ishi" (welded tuff), and hence it appears that the temperature of the "Shirasu" (unwelded) must have never been above $900^{\circ} \mathrm{C}$.

\section{"Artificial Shirasu"}

1. Larger fragments of the pumice in the "Shirasu". were artificially broken into fine pieces by crushing, by making collision, by rubbing, and by rolling down a slope. The materials thus obtained were cemented with URIX and cut into thin sections. Their micro-texture (Fig. 9) is similar to that of the "Shirasu."

2. Electron microscope reveals clearly the shape of the pumice powders with concave outline (Fig. 4d), resembling that of the "Shirasu" (Figs. 4a, 4b, 4c).

3. The mechanical analyses of the artificial powder present its size distribution diagrams (Table 3 and Figs. 10,11) similar to those of the natural "Shirasu" (Part I, p. 173, Fig. 5 and p. 175, Fig. 7), all of which belong to the type of bad sorting. 


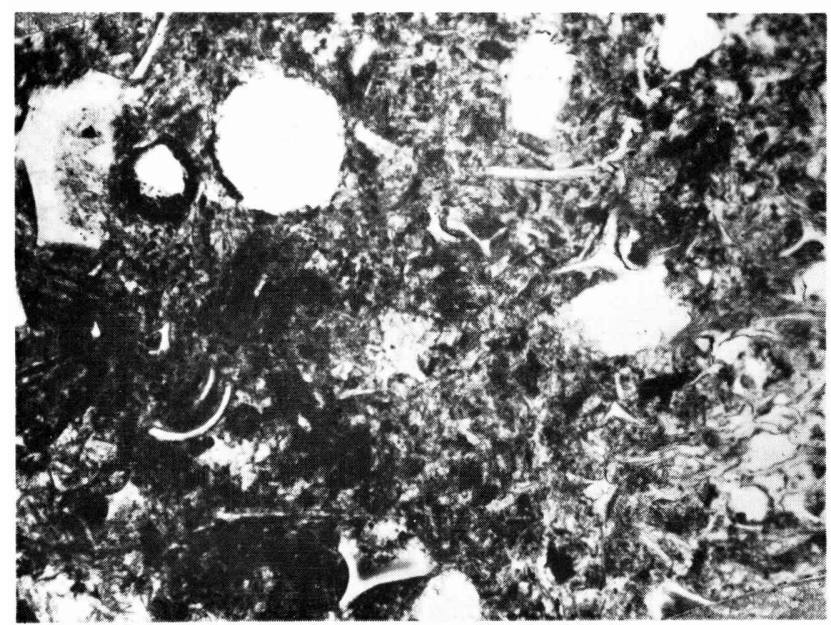

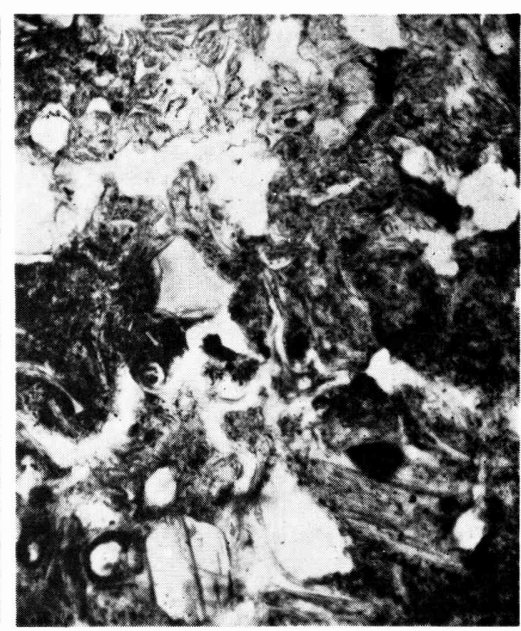

b
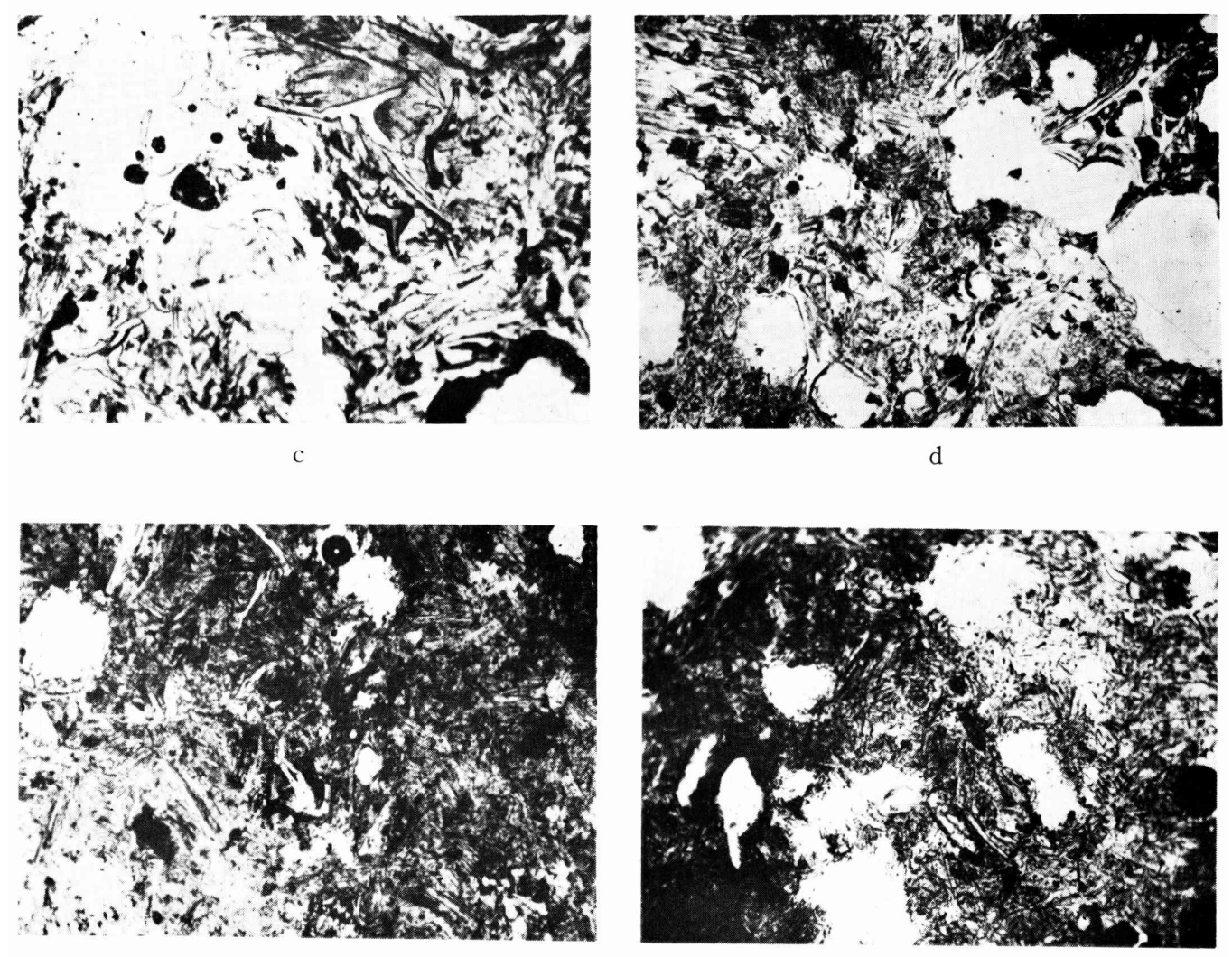

e

Fig. 9. Photomicrographs of the "artificial Shirasu," produced from pumice frag. ments by rolling down a slope ( $a$ and $b, \times 42)$, by crushing $(c, \times 96)$, by making collision ( $d$ and $f, \times 48)$, and by rubbing $(e, \times 48)$. 

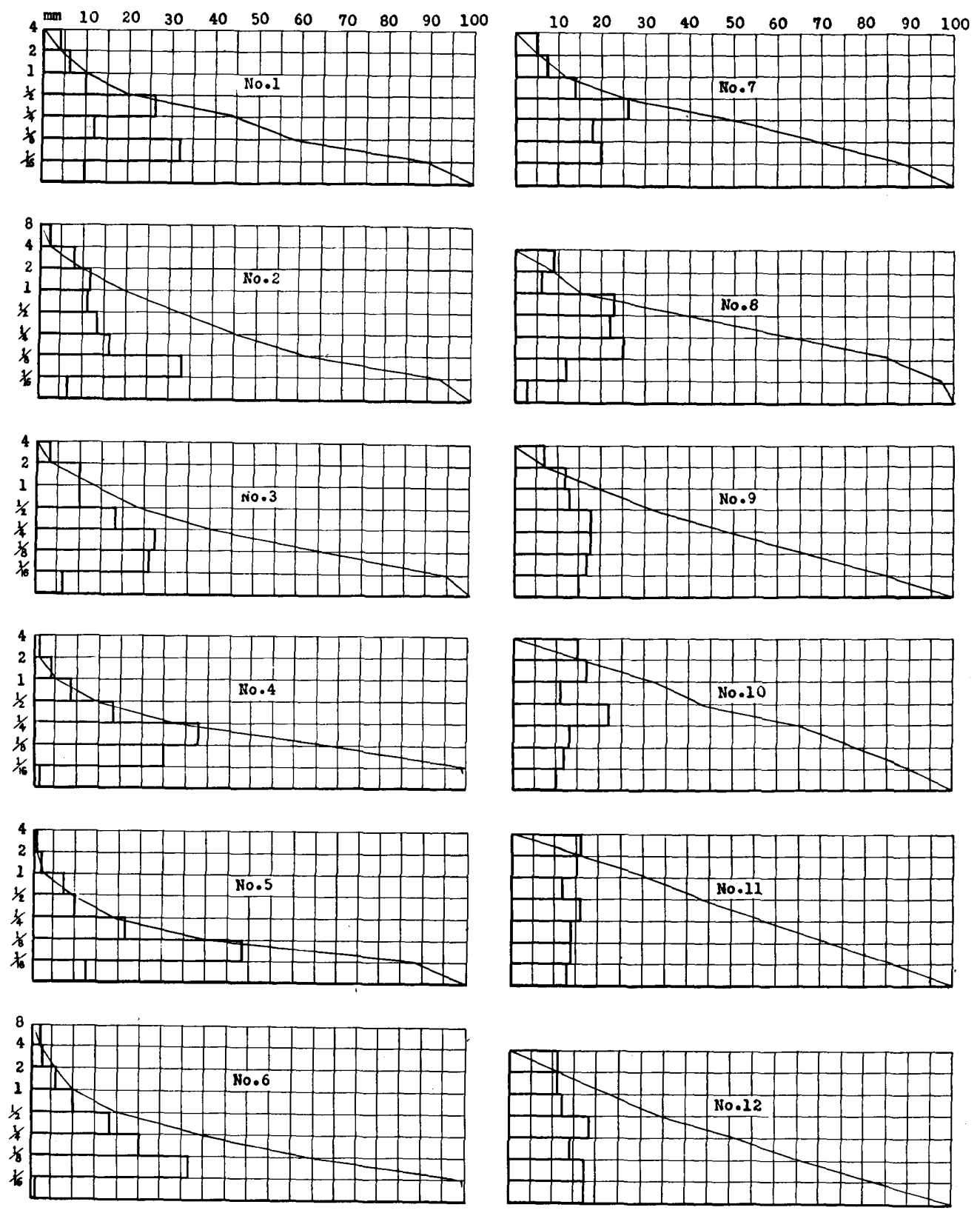

Fig. 10. Size-distribution diagrams for the "artificial Shirasu." (Nos. refer to Table 3)

\section{Concluding remarks}

All of the data given in this paper may again hold my opinion on the origin of the "Shirasu" for most parts, if not for the whole part, of it. Indeed, it is conceivable that the "Shirasu" should be a mixture of pumiceous fragments, 
Geological and Petrological Studies of the "Shirasu" in South Kyushu, Japan

Table 3. Size distribution of the "artificial Shirasu" (Total of 100)

\begin{tabular}{|c|rrrrrrrrrr|}
\hline Loc. No. Size (mm) & $8-4$ & $4-2$ & $2-1$ & $1-1 / 2$ & $1 / 2^{-1 / 4}$ & $1 / 4^{-1 / 8}$ & $1 / 8^{-1 / 16}$ & $1 / 16>$ & $\mathrm{Md}^{*}$ \\
\hline 1 & & 4 & 6 & 10 & 26 & 12 & 32 & 10 & 0.20 \\
2 & 2 & 7 & 12 & 11 & 13 & 16 & 32.5 & 6.5 & 0.20 \\
3 & & 3 & 10 & 10 & 18 & 27 & 26 & 6 & 0.17 \\
4 & & 1 & 3.5 & 8.5 & 18 & 38 & 30 & 1 & 0.16 \\
5 & & 0.5 & 1.5 & 7 & 10 & 21 & 48 & 12 & 0.11 \\
6 & 2 & 3 & 5 & 10 & 18 & 25 & 36 & 1 & 0.18 \\
7 & & 5 & 7 & 14 & 26 & 18 & 20 & 10 & 0.27 \\
8 & 9 & 6 & 23 & 22 & 25 & 12 & 3 & 0.35 \\
9 & & 12 & 13 & 18 & 18 & 17 & 15 & 0.24 \\
10 & & 17 & 11 & 22 & 13 & 12 & 10 & 0.4 \\
11 & 16 & 15 & 12 & 16 & 14 & 14 & 13 & 0.36 \\
12 & 11 & 11 & 12 & 18 & 14 & 17 & 17 & 0.24 \\
\hline
\end{tabular}

Particles and powders produced from pumice fragments by crushing. (Nos. 1, 2, 3), by making collision (Nos. 4, 8), by rubbing (Nos. 5,6 ), and by rolling down a slope (Nos. 7, 9, 10, 11, 12).

* Md: median diameter

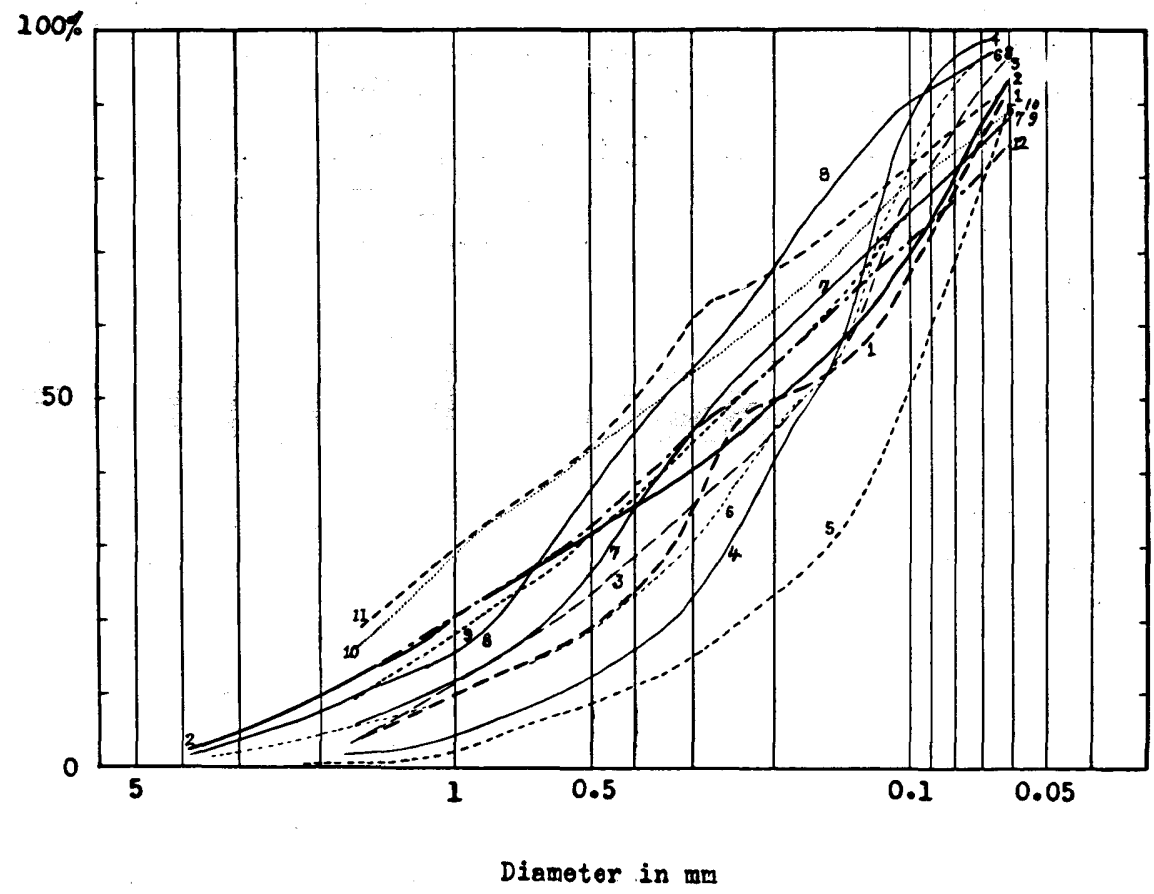

Fig. 11. Cumulative curves for the "artificial Shirasu," comparable to curves $S$ in Fig. 7 of Part 1. (Nos. refer to Table 3) 
powders produced by the various processes mentioned already, and some amounts of emitted ashes. In other words, in the pumice flows or nuées ardentes, pumice and pumiceous blocks and fragments collided with each other and have been crushed into fine pieces as they descended down the sides of volcano with rapid and varying velocities. In short, the "Shirasu" belongs to the category of "Pyroclastic flow" (William, 1941 ; Aramaki, 1956).

However, for conclusing the origin of the "Shirasu" with certainty, it is necessary to promote careful geological and petrological investigations of the whole "Shirasu" area so precisely that the circumstances of the "Shirasu" accumulation would be discussed.

\section{APPENDIX : Differential thermal analyses of decomposed "Shirasu"}

In general the "Shirasu" has often been altered by weathering to brown clayey soil. This alteration is the ultimate, if not immediate, cause of dangerous rapid landslides and earth falls along the "Shirasu" cliff, which have frequently destroyed farms and villages. For the provention from these disasters, there is an urgent need to know the properties of the clayey soil. The differential thermal analyses informed here may be a contribution to the properties. For analyses were prepared three samples of clay fractions of different grain sizes (coarse, medium, and fine), which were separated by means of a sedimentation method.

Each of the DTA curves shows not only two endothermic peaks, one at 135$150^{\circ} \mathrm{C}$ and the other at $530-550^{\circ} \mathrm{C}$, but also one exothermic peak at $940-945^{\circ} \mathrm{C}$ (Fig. 12). As to the amplitude of the peak, the first is larger than the second, which

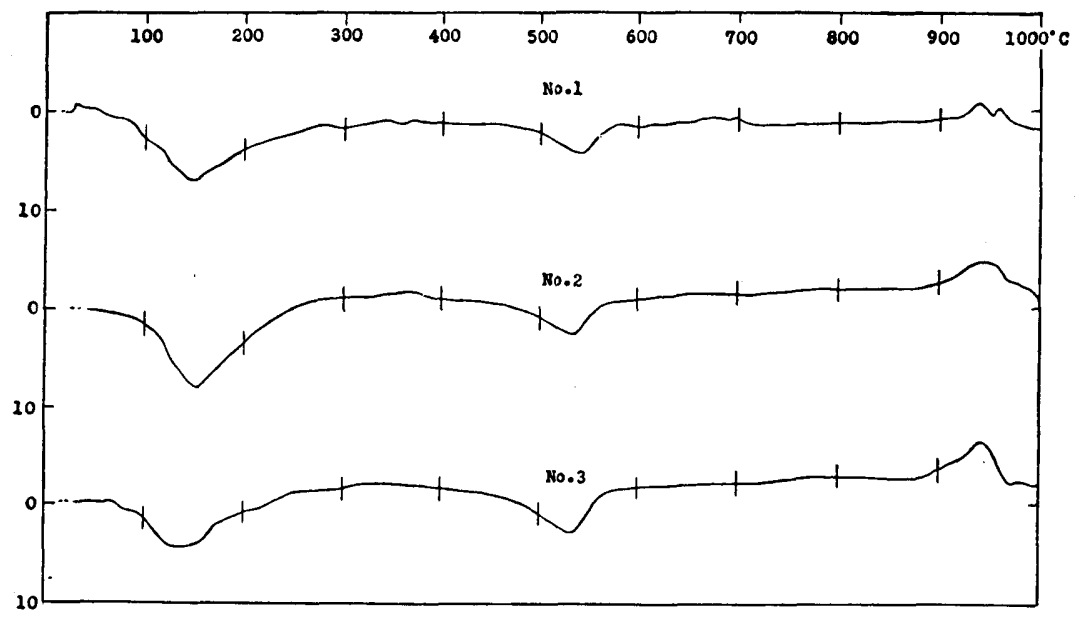

Fig. 12. Differential thermal analysis curves for the clay decomposed from the "Shirasu." No. 1. fine, No. 2. medium, No. 3. coarse fractions.

is as much as the third. Between the three peaks, the curves are uneven owing to some minor thermal reactions. Although the general shape of the curves resembles that of a mixture of hydrated halloysite and a considerable amount of 
allophane (Suno, 1953), it is not undoubted that a small amount of kaoline whould be mixed among them.

\section{Acknowledgment}

I wish to express my cordial thanks to Mr. N. Tanaka of the Department of Mining, Faculty of Engineering, Kyushu University, and Mr. S. Mryachr of our Department, who helped me in my experimental work. For load bearing test I am indebted to Dr. N. Inenoue, Director of the laboratory of Kurosaki Yogyo Company, Yahata City. Professor T. Tomita of our Department read this paper in manuscript with inspiring criticism.

This work has been done on the Grant in Aid for Scientific Researches from the Ministry of Education, Japan.

\section{References Cited}

Aramaki, S. (1956). Classification of "Pyroclastic flow." Jour. Geo. Soc. Japan. 62, 356. (in Japanese).

Gillbert, C. M. (1938). Welded Tuff in Eastern California. Bull. Geol. Soc. Am., 49, 1829-1862.

Kuno, H. (1941). Characteristics of Deposits Formed by Pumice Flows and Those by Ejected Pumice. Bull. Earthq. Res. Inst., 19, 144-148.

LACrolx, A. (1904). La Montagne Pelée et ses Eruptions, (Paris). [Ref. Moore (1934).]

Moore, B. N. (1934). Deposits of Possible Nuée Ardente Origin in the Crater Lake Region, Oregon. Jour. Geol., 42, 355-375.

Shapp, R. P. and Nobles, L. H. (1953). Mud Flow of 1941 at Wrightwood, Southern California. Bull. Geo. Soc. Am., 64, 547-560.

Sudo, T. (1953). "Clay Minerals" (Iwanami Zensho). 56-74 (in Japanese).

TANedA, S. (1954). Geological and Petrological Studies on the "Shirasu" in South Kyushu, Japan. Part I. Preliminary Note. Mem. Fac. Sci., Kyushu Univ., Geology, 4-2, 167-177.

(1953). Explanately Text of the Geological Map (Scale 1:200,000) of Kagoshima (in Japanese). Published by the Prefectural Office.

Verhoogen, J. (1951). Mechanics of Ash Formation. Am. Jour. Sci., 249, 729-739.

William, H. (1941). Calderas and Their Origin. Bull. Dept. Geol. Sci., Univ. Calif. Publ., 25, 239-346. 